\title{
松代群発地震の初期発展過程
}

\author{
原子力安全基盤機構* 浜 田 信 生 \\ 気象庁精密地震観測室** 野 坂大 輔 \\ 大阪管区気象台*** 小林 正志・吉川一 光 \\ 気象庁地震火山部**** 石 垣 祐三・田利信二朗
}

\section{Initial Development of the Matsushiro Earthquake Swarm}

\author{
Nobuo Hamada \\ Japan Nuclear Energy Safety Organization (JNES), \\ 4-1-28 Toranomon, Minato-ku, Tokyo 105-0001, Japan \\ Daisuke NosAKa
}

Matsushiro Seismological Observatory, 3511 Nishijo, Matsushiro, Nagano 381-1232, Japan

Masashi Kobayashi and Kazumitsu Yoshikawa

Osaka District Meteorological Observatory, 4-1-76 Otemae, Chuo-ku, Osaka 540-0008, Japan

Yuzo IsHigaki and Shinjirou TARI

Seismological and Volcanological Department, Japan Meteorological Agency, 1-3-4 Otemachi, Chiyoda-ku, Tokyo 100-8122, Japan

(Received January 5, 2012; Accepted March 6, 2012)

\begin{abstract}
Matsushiro earthquake swarm is a most well known and well studied earthquake swarm in the history of seismology. From viewpoints of geophysics, geology and geochemistry, various observations, field surveys and analyses had been made to reveal characteristics of the swarm. On the basis of these studies, several models had been proposed to explain why and how the swarm originated and developed. However, majority of studies had focused on the activity around the climatic stage of the swarm in 1966 and so far, studies on the initial stage of the swarm in mid 1965 had remained few due to lack of sufficient observation data. The exact area where the swarm was born had not been known and the swarm was vaguely believed to originate from the area around Mt. Minakami in former Matsushiro town (now belongs to Nagano city). Considering that the manner of initial development of swarm activity represents an important characteristic of the swarm earthquake, we tried to get more clear view about initial stage of the swarm activity in this study. We re-investigated seismograms obtained by routine observation and studied seismograms of temporal stations for the first time which had not been processed yet. By scanning analogue seismograms, we made a complete data set of S-P times with high precision for each station. Although the data set of S-P times from two stations are not sufficient for conventional hypocenter location, we were able to narrow down a possible source area of the swarm activity under the reasonable assumptions. By considering direction of initial motion of $\mathrm{P}$ waves and assuming local velocity model of the upper crust in the region and plausible focal depth of $4.5 \mathrm{~km}$ of the swarm earthquake, we found that the area of swarm in the very beginning in August, 1965 is located about $4 \mathrm{~km}$ north-east of the Matsushiro earthquake fault (MEF) in former Wakaho town near its border with former Matsushiro town. Size of the initial
\end{abstract}


swarm area was $3-4 \mathrm{~km}$ in diameter. While swarm activity in the initial region was gradually decaying in September new swarm activity appeared separately from the initial swarm area around southern and south-west part of the MEF. Activity in the new swarm area had been increasing and it was developed to more intense swarm after October, 1965 when establishment of temporal seismic station network of the Earthquake Research Institute, University of Tokyo enabled detailed hypocenter location. The new swarm area coincides with the area where large amount of ground water moved upward and was released on the ground surface in the climatic stage of the swarm. It was well known that source area of the swarm was split and expanded toward north-east and south-west after March, 1967 in its climatic stage. Present study on the initial development of swarm area suggested that characteristics of the Matsushiro earthquake swarm such as splitting and expansion of its source area toward northeast and southwest were inherent in their early stage of the activity in August and September, 1965.

Key words: Matsushiro earthquake swarm, Matsushiro earthquake fault, Ground water

\section{§1. はじめに}

1965 年 8 月に長野市松代町付近で始まった松代群発 地震は, 主な活動だけでも 2 年近くにわたり， $M_{\mathrm{j}}$ (気象 朾マグニチュード） 5 以上の地震も 19 回を数えるなど, 内外をとわず代表的な群発地震として知られている. 群 発地震の発生に伴い起きた地殼変動や, 地表に現れた地 割れなどは, 個々の群発地震との関係は明らかではない が, 松代町の北東部, 皆神山の北側に, 北西南東に走向 を持つ松代地震断層の左横ずれの活動が推定されている [Nakamura and Tsuneishi (1966)].また我が国では詳細 な観測調査研究が行われた初めての群発地震であり, 地 震学研究の歴史の中でも重要な地位を占める出来事で あった，群発地震に関する調查研究は多岐にわたり, 群 発地震の最中, 直後ばかりでなく群発地震が終息後半世 紀にわたり, 色々な角度から研究が行われてきているこ とから,これまで主な検討課題はほとんど網羅しつくさ れたように見える。しかしながら群発地震の全過程を眺 めてみると, 1965 年 8 月上旬から地震研究所による臨 時観測網が展開され本格的な観測調查が始まった 10 月 中旬までの 2 ケ月あまりの初期段階の活動に関する調查 研究は極めてそしく, わずかに気象庁 (1968) に触れられ ている程度である. Fig. 1 は群発地震の有感地震回数の 変遷を示しているが, 拡大表示した初期の 3 ケ月の活動 はほとんど調查されていないことになる。これは当時の 地震観測網の検知能力が低く, 初期段階では臨時の観測 体制も整っていないため, 調查の材料が至しかったこと が，主な原因である。

一般に群発地震の活動は, 和歌山市付近の微小地震活 動のように数十年にわたって継続するものは別として, 松代群発地震のような激しい活動が年を超えて継続する 例は少数である.たとえば群発地震活動の始まりから最 盛期に至る時間は, 伊豆半島東方沖の群発地震の例では 数日から 1 週間程度が多く, 2000 年の三宅島噴火に伴っ て周辺の海域で発生した群発地震でも 10 日間程度に過
ぎない，これらの群発地震では，短い場合は時間単位で 地震の発生する場所の移動や拡大などの活動の変化が起 きる.このように初期の群発地震の発展の様子は, 群発 地震の特徵を示す重要な要素の一つであるが, 松代群発 地震の場合, 最近の群発地震の例に見られるような詳し い様子は不明のままである。本調査は, 保存されている 資料を基に, 初期の群発地震の活動の様子を出来るだけ 明らかにすることを目的に行った。

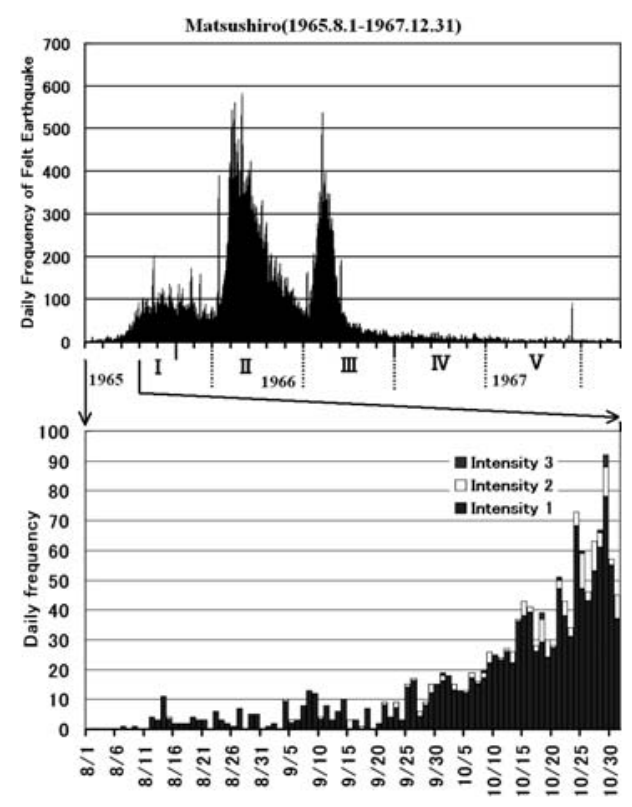

Fig. 1. Daily number of felt earthquake observed by the Matsushiro seismological observatory (MAT) during the period from Aug. 1, 1965 through Dec. 31 (upper figure), 1967 and daily number of each seismic intensity event (in JMA seismic intensity scale) during the first 3 months (lower figure). Five stages (I-V) of the swarm activity is after Hagiwara and Iwata (1968). 


\section{§ 2. 初期の観測資料}

1965 年 8 月 3 日に地鳴りを伴った地震が, 松代町に ある気象庁地震観測所（観測点の略号 MAT, 現在の気 象庁精密地震観測室，以下松代と略す）の地震計に記録 されたのが，群発地震の始まりとされている[例えば， 松代地震センター(1982)]。当時, 松代では世界標準地 震計 (WWSS) の設置が終わり，観測が開始されたばか りであったが，WWSS の短周期地震計 3 成分以外に, ほほ同等の特性を持つフィルム記録のベニオフの短周期 地震計 3 成分，固有周期約 1 秒の上下動地震計などの高 感度地震計による定常観測がすでに行われており，これ らの微小地震を記録している，松代の定常観測の地震計 は機械式強震計を除きいずれも光学式であり，アナログ で測定レンジが限られるばかりでなく，信号が大きいと 記録がかすれて見えないなど検測に関する制約も大き かったままた記録速度も $60 \mathrm{~mm} / \mathrm{s}$ から $15 \mathrm{~mm} / \mathrm{s}$ と遅く 時間分解能が低いため, 小さな観測ネットで震源を決め るには制約が大きかった。

群発地震の活発化に伴い, 気象庁では松代町周辺で Fig. 2 に示すように臨時観測を実施している。 また少数 ではあるが, 有感地震については, 長野, 松本などの定 常観測点で検測值が得られている他，浅間山の火山観測 用の地震計にも記録がある. Fig. 3 に今回の調查に利用 した地震観測点を示す。臨時観測点の位置は, 本間・他 (2006)の調査結果を利用した.

10 月に入ると地震研究所により, 象山, 赤柴, 保科 に臨時観測点が展開され，10月10日からは，3点の S-P 時間を用いて震源が決定されるようになり，その後

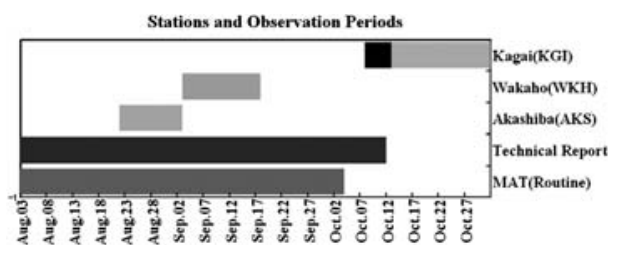

Fig. 2. The figure shows periods of observations and available period of data for Matsushiro (MAT). Periods of temporal observation in Akashiba, Wakaho and Kagai are shown by gray colored bars and black portion of Kagai indicates the period of phase reading by this study. Period of data for MAT available from Japan Meteorological Agency (1968) and period of phase data registered in the station book of the Matsushiro seismological observatory are also shown. The same short period seismograph was employed in temporal observations at Akashiba, Wakaho and Kagai.
群発地震の活動域の拡大とともに観測点は南側の森にも 増設された [Hagiwara and Iwata (1968)]. 従って, 8 月 6 日から 10 月 9 日までの間は, 多点観測による震源 分布はこれまで得られていない.

Fig. 4 は, 松代 1 点の 3 成分の $\mathrm{P}$ 波初動方向の振幅比 と S-P 時間から求めた, この時期としては唯一の震源の 分布である[気象庁 (1968)]。しかしながら, 光学式の 記録から初動振幅を正確に読むことの困難さに加え, 振 幅比から求めた震源の決定誤差の評価も難しい。 また震 源距離を求めるために仮定した $\mathrm{P}$ 波の平均速度 $4.6 \mathrm{~km} / \mathrm{s}$ という地震波速度は, Asano et al. (1969) など今日明ら かにされている構造にくらべ過小である。また大森係数 $6.3 も$, The party for seismographic observation of Matsushiro earthquakes and Seismometrical section

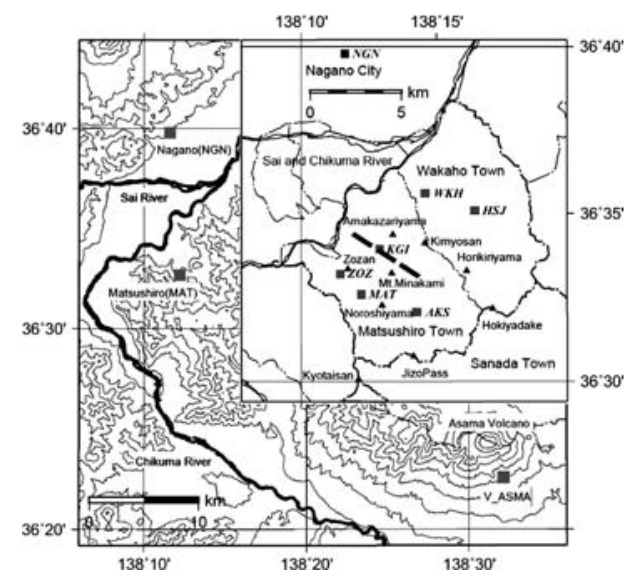

Fig. 3. Solid squares indicate permanent and temporal seismic stations around Matsushiro town, Nagano city used in this study. MAT, NGN (Nagano) and V_ASMA (Asama volcano) in the large area map shows permanent seismic stations operated by the Japan Meteorological Agency (JMA) and AKS (Akashiba), WKH (Wakaho) and KGI (Kagai) in the small area map were temporally set up JMA stations. ZOZ (Zozan), HSJ (Hoshina) and AKS (Akashiba, the same abbreviation with the nearest temporal station of JMA but different observation period) were temporally set up by the Earthquake Research Institute[Hagiwara and Iwata (1968)]. A thick broken line with northwest to southwest strike shows the Matsushiro earthquake fault inferred from field survey [Nakamura and Tsuneishi (1966)] and crustal movement observation [Kasahara (1970)] and also shown are city and town borders (hatched lines), prominent geographical points (triangles) and rivers. 


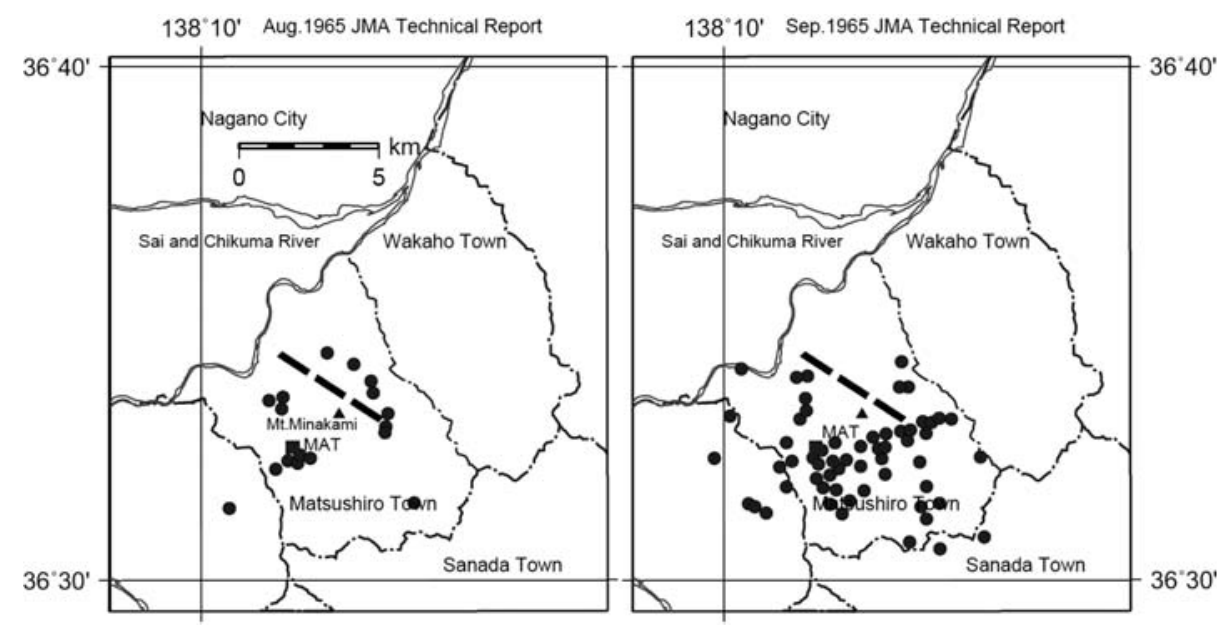

Fig. 4. Plain view of epicenters located by single station method in August (left) and September (right), 1965 after the Figure 2.3.2 of Japan Meteorological Agency (1968). Direction of epicenters from the station were estimated from amplitude ratio of three components initial motions of $\mathrm{P}$ waves and distance and focal depth were estimated from S-P times and incident angle of $\mathrm{P}$ waves observed by the Matsushiro seismological observatory (MAT). A two layers velocity model with $2.7 \mathrm{~km} / \mathrm{s} \mathrm{P}$ wave velocity of surface layer and $5.6 \mathrm{~km} / \mathrm{s} \mathrm{P}$ wave velocity of base layer and Omori's constant $k=6.3$ were assumed.

(1966) [以後, 震研観測班 (1966) と略す］が震源決定に 用いた大森係数 7.39 に比べ小さい. 臨時観測点に比べ 岩盤が地表に露出している松代での大森係数はさらに大 きくなるはずで, 大森係数の過小評価は, 震源を観測点 に近い地域に集めて決めている可能性が高い.

今回は, 保存されている記録から, 地震を新たに読み 取り或いは再読み取りを行い, 多点の検測值による震源 決定, 再検測による精密な S-P 時間の組み合わせによ り, 群発地震の活動域の空間的, 時間的な変化の抽出を 試みた。

\section{§ 3. 3 点観測の読み取りによる震源の分布}

1965 年 8,9 月の期間, 軽井沢の火山観測点（浅間山 A 観測点 V_ASMA）の記録から松代群発地震の読み取 りを行い, 松代, 長野の 3 点の検測值により $\mathrm{P}$ 及び $\mathrm{S}$ 相の到達時間を用いた最小自乗法により震源決定を行っ た. 速度構造については, 気象庁の標準速度構造 [JMA 2001，上野・他 (2002)］を用いた. 臨時観測点の赤柴, 若穂の記録については, 時刻補正量が不明のため, 震源 決定には活用出来なかった。長野, 軽井沢の検測值につ いては, Asano et al. (1969) など地殼構造探査の結果が 示すように表層の $4 \mathrm{~km} / \mathrm{s}$ 層の不連続など, 速度構造の 違いによる走時偏差が認められるので, 10 月以降の多 数の観測点の検測值による震源決定結果から求められる 走時残差の平均值, 長野の $\mathrm{P}$ 波, $\mathrm{S}$ 波についてはそれぞ
れ 0.22 秒と 0.73 秒, 軽井沢については, 0.46 秒, 1.86 秒を観測点補正值として加え決定した震源を Fig. 5 に 示す. 観測点配置が偏ることや, 読み取り誤差などから, 震源は大きくばらついている. Fig. 4 の P 波初動から求 めた震央分布よりもばらつきは大きく, この結果から群 発地震初期の活動域の空間的広がりを推定することは困 難である.しかしながら, 8 月と 9 月の震央分布を比較 すると， 8 月にくらべ 9 月の活動は平均でみると南西側 にずれていることが分かる。このことは群発地震活動が 始まった初期の 2 ケ月間に活動域の変化があったことを 示唆しており Fig. 4 からも変化の傾向は伺える.

\section{§4. 各観測点の S-P 時間頻度分布の比較から推定さ れる群発地震の活動域}

松代および臨時観測点の記録から S-P 頻度分布を調 ベ, 比較すれば, 群発地震の空間的な広がりを把握でき る可能性がある。ただし臨時観測点の赤柴, 若穂は観測 期間が重ならないため, 震源の推定に用いる観測点は松 代といずれかの 2 点に限られる. 赤柴, 若穂の記録はこ れまで読み取りが行われておらず，新たにS-P 時間の読 み取りを行った。松代については定常観測の検測值が残 され近年, 古いデータ活用のための地震観測原簿のディ ジタル化など整備 [北村・他 (2006)］が行われているが, 内容を見ると群発地震に対する対応方針が定まらず，検 測基準, 読み取りを行う地震計の記録の種類も日々異な 


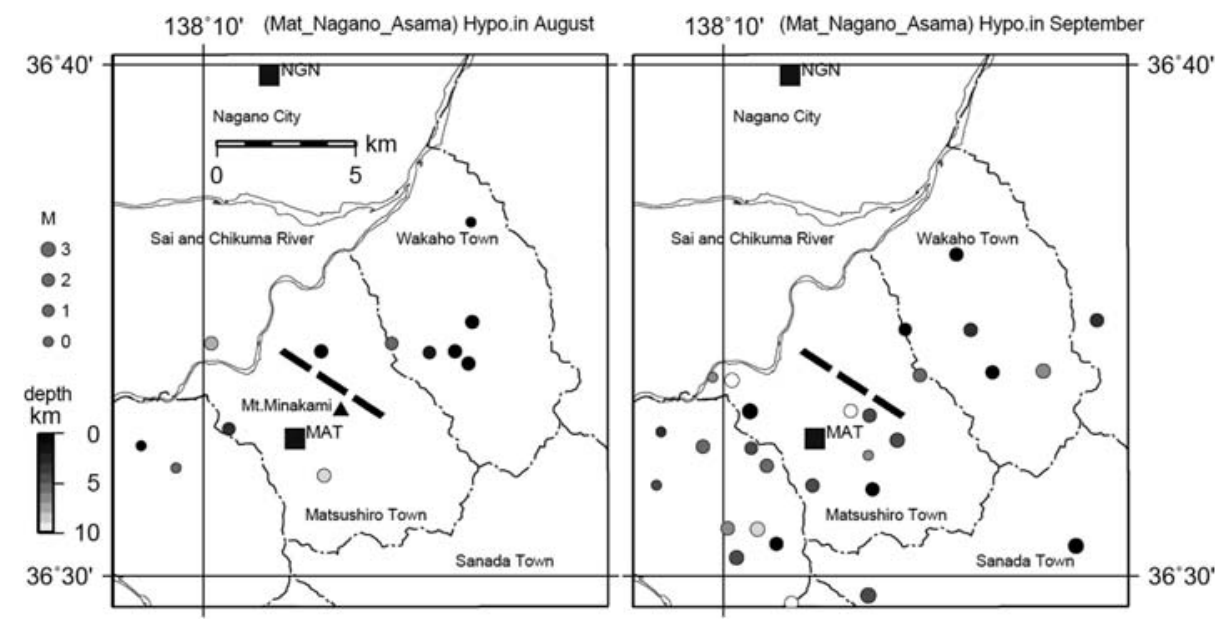

Fig. 5. Epicenters in August (left) and September (right), 1965 located by using phase data of three stations (MAT, NGN and V_ASMA). Due to heterogeneity in the upper crust of the region, station correction values $(0.22 \mathrm{~s}$ and $0.73 \mathrm{~s}$ for P and $\mathrm{S}$ arrivals at NGN and $0.46 \mathrm{~s}$ and $1.86 \mathrm{~s}$ at V_ASMA respectively) were employed in the location. Although epicenters show large scattering and location errors, there is a tendency that epicenters in September exist relatively southwest of those in August.

るため，検測值は均質なデータセットとは言い難い，臨 時観測と重なる 8 月 22 日から 9 月 17 日の期間について は，均質な検測值を得るために再検測を行った。いずれ の観測点についても紙送り $1 \mathrm{~mm} / \mathrm{s}$ のアナログ記録を 600 bpi の分解能を持つスキャナーでスキャンし 1/100 秒位まで読み取り，1/20秒の分解能を確保した。また 精度をできるだけ確保するために，水平 2 成分または 3 成分の S-P 時間の読み取りが得られる地震に限定し, 水 平 2 成分しか読み取れない場合は值の差が 0.1 秒以下, 3 成分の読み取りについてはその差が 0.15 秒以下の場合 に限定し，平均値をもって S-P 時間とした。

8 月 22 日から 9 月 2 日までの松代, 赤柴の S-P 時間 を比較プロットした結果を Fig. 6 (a) に示す. 松代の S-P 時間 1.1 秒，赤柴の S-P 時間 1.0 秒を中心に S-P 時間士 0.15 秒の範囲に多くの地震がプロットされ, 群発地震初 期の一つの活動域を表している，両観測点により近い S-P 時間 0.9 秒以下の地震の多くは観測期間の最後に現 れたもので, 活動域の変化があったことを示している.

次に 9 月 3 日から 17 日までの松代と若穂の S-P 時間 を比較プロットした結果を Fig. 6 (b) に示す. 若穂に近 い地震が上方（北）に示されるよう, 若穂の S-P の時間 軸を逆にして表示している。 これらの図からこの時期の 活動は点線及び破線で囲まれる A, B の 2 つの活動域に 分かれることが分かる。 またそのうち A は，松代の S-P 時間の分布が初期の (Fig. 6 (a)) と同じであり, 群発地震 の初期の活動域が Fig. 6 (b) の A， 8月の最後から 9 月
になって活発化した活動域がB に対応していることが 分かる.ささらにFig. 6 (b) を前半後半の期間に分けて見 た結果を Fig. 6 (c), (d) に示す. 前半後半を比較すると群 発地震活動の中心が A の領域から B の領域に移りつつ あることが分かり, 後半になると新たにCの領域に新 しい活動が現れることが分かる.

$2 つ の$ 観測点の S-P 時間から震源を一意的に決めるこ とは不可能であるが, 震源の深さや速度構造を仮定でき れば， $\mathrm{P}$ 波の初動方向の情報を利用して地震の発生域を ある程度絞り込むことが可能である。気象庁 (1968)によ れば，松代で観測された群発地震の初動は，初期にはす べて押しであったと言われている。事実，半旬毎の初動 の押し引きの割合を示した Fig. 7 から, 群発地震の初動 は，少なくとも最初の1 个月間はほとんど押しであった ことが分かる。松代群発地震の発震機構解は，ほぼ東西 に主圧力軸を持ち，節面が地表に垂直な横ずれ断層夕イ プであることが知られている [Ichikawa (1969)など]. もし初期から発震機構が変わらなかったとすれば, 松代 の観測点に対し地震の活動域は, 観測点の北方もしくは 南方に存在することになる. これらの地震の内, 水平動 の $\mathrm{P}$ 波の初動方向が明瞭な地震の初動は, 大部分が南 西の押しであり, 主な地震の発生域が松代の北東象限に 限られることを示している。 また活動が活発化した 10 月以降は, 後述のように多点観測のデー夕を用いて決め られた群発地震の深さは $4 \sim 5 \mathrm{~km}$ に集中している。初 期の地震も深さ $4 \sim 5 \mathrm{~km}$ で発生していたと仮定すれば 

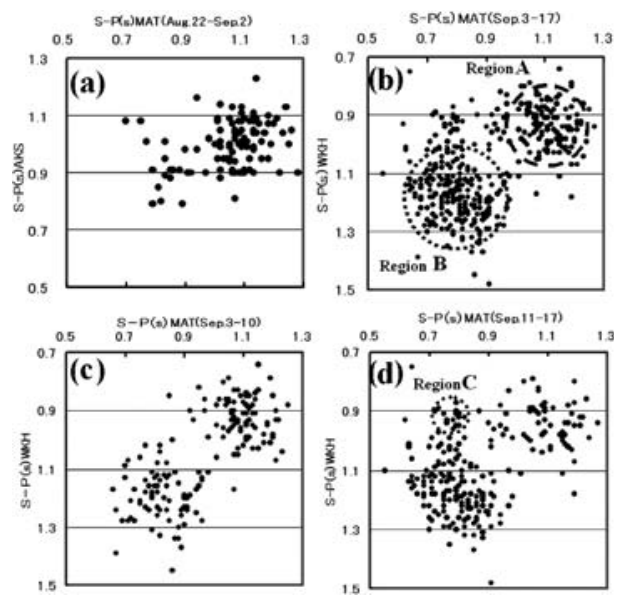

Fig. 6. A plot of S-P times of Matsushiro earthquakes observed at MAT and AKS (a) during the period from Aug. 22 through Sep. 3, 1965 and observed at MAT and Wakaho (b, c, d) during the period from Sep. 3 through Sep. 17, 1965. A swarm activity indicated in the broken circle (A) in (b) (Sep. 3-Sep. 17) corresponds to the initial activity of the swarm indicated in (a) (Aug. 22-Sep. 3). An activity in the dotted circle (B) in (b) represents a new active area after September, 1965 appeared to the south-west of the initial seismic area. An activity in $\mathrm{b}$ are divided in the period (c) (Sep. 3-Sep. 10) and (d) (Sep. 11Sep. 17) showing that initial activity $A$ in $b$ are decaying while activity $\mathrm{B}$ became prominent and new activity $\mathrm{C}$ in a dotted circle was born in the later stage in (d).

\section{地震の発生域の推定が可能である.}

震源を推定するには, 観測点直下の速度構造が必要と なる。速度構造については, 南雲・他 (1967), Asano et al. (1969), 浜田・柏原 (1981), 長田・他 (1984)などを参 照し，また震研観測班 (1966) や気象庁 (1968) で震源決定 に用いた構造も参考にしたが，いずれも松代以外の観測 点直下についての速度構造に関する直接的な情報は含ま れていない.この地域の上部地殼の $\mathrm{P}$ 波速度は, 5.4 $6.0 \mathrm{~km} / \mathrm{s}$ と推定されており, ここでは $5.6 \mathrm{~km} / \mathrm{s}$ を仮定 した．表層のP 波速度は，2.0〜 $4.0 \mathrm{~km} / \mathrm{s}$ の值が得られ ているが, 表層の厚さは場所により異なっている. 以上 の状況に鑑み, 各観測点について, Table 1 に示す速度 構造を仮定した。なお松代 (MAT)については, 広帯域 地震計の深井戸への設置工事の際, Fig. 8 に示す速度検 層の結果が得られており[露木・他 (2009)], 速度の遅 い表層は考慮する必要がないと考えられる.

まず 8 月 22 日から 9 月 2 日までの松代-赤柴の S-P 時

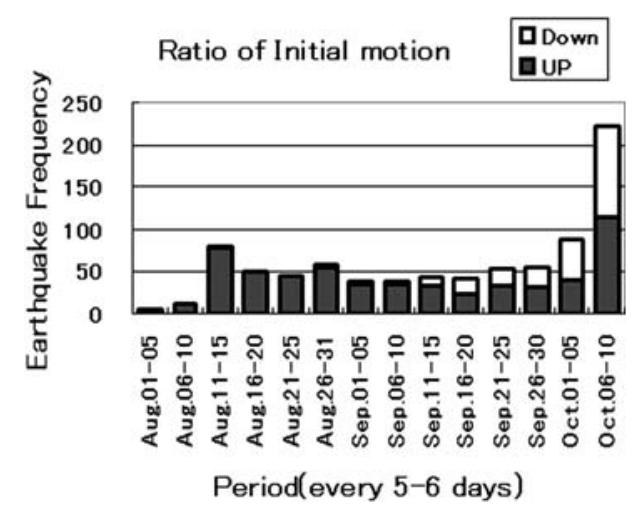

Fig. 7. Ratio of initial motion of vertical component $\mathrm{P}$ waves in every five or six days observed at MAT during the initial stage of the swarm activity. Upward initial motions were predominant in August, 1965. However, number of earthquakes which show downward initial motion increased gradually in September and October showing that directions of epicenter from MAT were diversified.

Table 1. Thickness and $\mathrm{P}$ wave velocity of surface layers at Wakaho (WKH), Akashiba (AKS) and Matsushiro (MAT) assumed for determination of epicenters using combination of S-P times. $\mathrm{P}$ wave velocity of $5.6 \mathrm{~km} / \mathrm{s}$ for base layer and focal depth of $4.5 \mathrm{~km}$ were also assumed in the estimation.

\begin{tabular}{lccc}
\hline & WKH & AKS & MAT \\
\hline Surface Layer Depth $(\mathrm{km})$ & 1.0 & 0.2 & 0.1 \\
\hline P Wave Velocity $(\mathrm{km} / \mathrm{s})$ & 2.0 & 4.0 & 5.0 \\
\hline
\end{tabular}

間と, 松代の北東象限という初動方向の組み合わせから 推定される震央を Fig. 9 (a)に, 9 月 3 日から 17 日に発 生した地震の内, 若穂の S-P が松代より短く, 松代-赤 柴の組み合わせに対応すると考えられる震央を Fig. 9 (b)に示す. 震央の位置は仮定した速度構造の影響を受 け, 速い構造を仮定すると, より北東側に決まり, 遅い 構造或いは震源の深さを深く仮定すると, 観測点よりに 移動するが, 移動範囲は $2 \sim 3 \mathrm{~km}$ 程度であり, 松代地 震断層の北東側に存在したことは確実と思われる. Fig. 9 (a)の震源は Fig. 6 (a)に, Fig. 9 (b) は Fig. 6 (b) の Region A に示すグループの地震にそれぞれ対応している. $2 つ の$ 観測点の組み合わせにより推定した地震の発生域 もほぼ一致しており, 妥当なものと考えられる。松代若穂の組み合わせで推定される震源は, 松代と若穂を結 
ぶ線の北西側に存在する地震もあると思われるが, 松代赤柴の結果と比較すると数は少ないものと考えられる. これらから松代群発地震の最初の活動は, 旧若穂町の中 心から旧松代町との境界にかけての地域で始まったこと

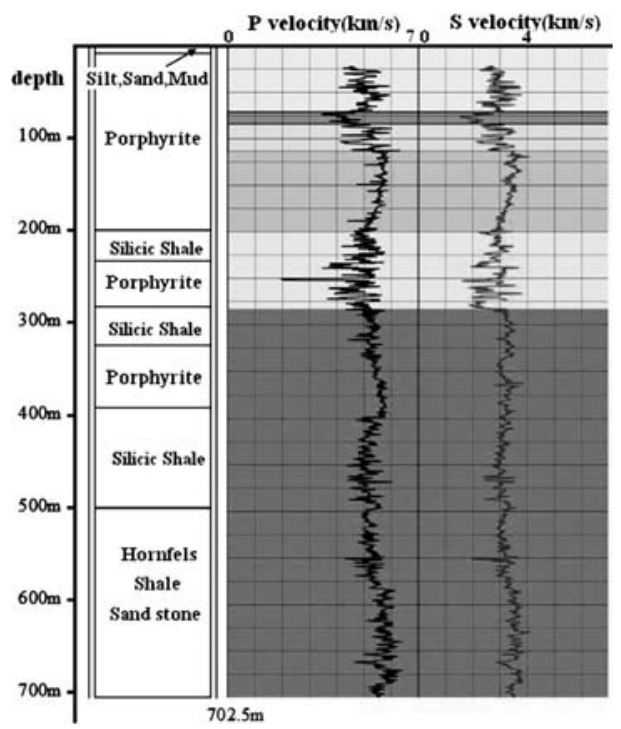

Fig. 8. Velocity profiles of $\mathrm{P}$ and $\mathrm{S}$ waves and geology at the deep borehole for seismometer of the Matsushiro seismological observatory after Tsuyuki et al. (2009).
が明らかとなった。

次に 9 月 3 日から 17 日にかけての松代-若穂の S-P 時 間から推定される震源の内, Fig. 6 (b) の region B で示 される松代に近い領域で発生している地震については, 初動方向が一定せず震源が観測点からみて色々な方位に 分布する可能性を示しており，また 3 成分の初動が明瞭 な地震は稀であり，Fig. 10 に示すように松代-若穂を結 ぶ線の北西側に震源が存在するか, 南東側にあるかを絞 り込むことが困難である。しかし後述の 10 月以降の活 動や信頼度は劣るが, Figs. 4, 5 の震源との対応を考え ると多数の地震は南東側に位置する可能性が高いと考え られる (以後 B 領域と呼ぶ).

以上から S-P 時間を用いた震源の推定結果は Fig. 11 のようにまとめられる。群発地震は 1965 年 8 月に松代 地震断層の北側の $\mathrm{A}$ 領域で始まり，9月に入ると断層 の南端部分及び南側の $\mathrm{B}$ 領域であらたな活動が始まり 活発化した。おそらく初期の地震活動により断層の端の 部分に応力が集中する状態が生まれたと考えられる，9 月に入ってからのS-P 時間の分布の広がりを見ると，南 側の活動はさらに拡大を続けたと思われるが，9月中旬 以降 10 月中旬までは活動域を推定する資料がそしく 10 月以降の活動との関連から推測せざるを得ない.

\section{$\S 5.1965$ 年 10 月から 12 月の地震活動}

1965 年 10 月に入ると地震研究所は, 松代町の赤柴,

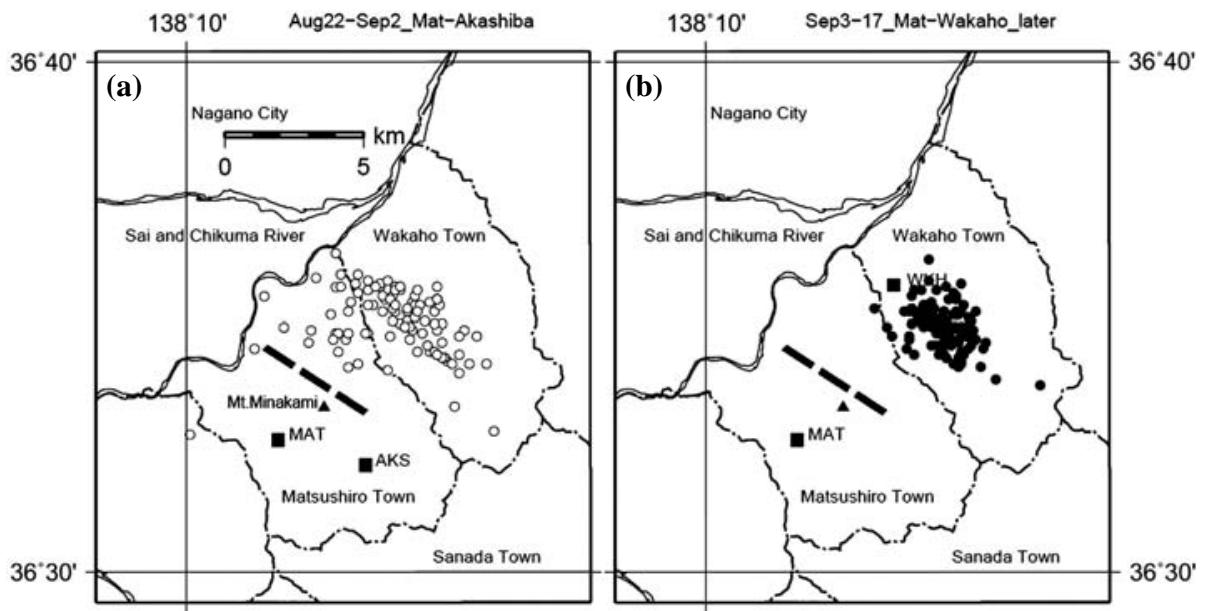

Fig. 9. Epicenters estimated by combing information of S-P times and direction of epicenters from MAT inferred from initial motions are shown. Epicenters during the period from Aug. 22 through Sep. 3, 1965 (open circles) estimated from the data of MAT and AKS are on the left (a) and those during the period from Sep. 3 through Sep. 17. (solid circles) estimated from the data of MAT and WKH are on the right (b). Swarm activity A in Fig. 6 (b) are selected and indicated in the right (b). Focal depth of $4.5 \mathrm{~km}$ and crustal model of each station in Table 1. were employed in the estimation. 


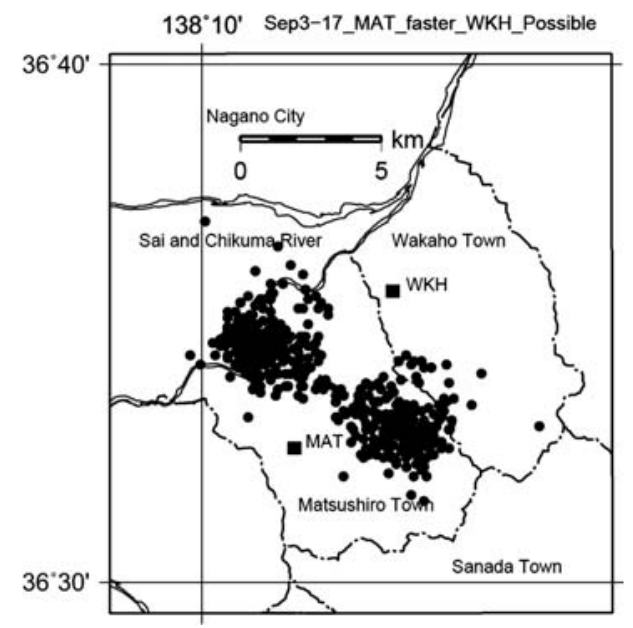

Fig. 10. Possible epicenters of earthquake activity $\mathrm{B}$ in Fig. 6 (b) estimated by combination of S-P times data of MAT and WKH during the period from Sep. 3 through Sep. 17, 1965. Due to a lack of initial motion data at MAT after mid September, direction of epicenters are not controlled by initial motion of $\mathrm{P}$ waves and both possibilities of epicenters on the north-west side of the MATWKH line and on the south-east side of it are not eliminated. However, swarm activity after October, 1965 is suggesting that plausible epicenters in this period was existing mostly in the southwest area.

象山 (ZOZ), 若穂町の保科地区 (HSJ) に設けた観測点の 観測值の S-P 時間を用いて震源を決めるようになり群発 地震の活動域の詳細が明らかになってきた。しかし今回 明らかになった 8 月 9 月の活動域との対応は, 時間的間 隔もあることから明確ではない。また 3 点の S-P 時間で 決めた震源については, 震源決定誤差の評価が困難であ る.

そのため, 地震研究所, 気象庁の観測值を統合して改 めて震源決定を行った。気象庁では赤柴, 若穂の臨時観 測は撤収したが，10月に入ると松代町の加賀井 (KGI) に新たに臨時観測点を設け再び観測を始めている [気象 庁 (1968)]. 地震研究所の赤柴, 象山, 保科に加え, 気 象庁の松代, 加賀井, 震源域からやや離れている長野で 同時に観測された地震を対象に絞り震源を調査した。そ のため加賀井については一部再検測を行いデータを補足 した。松代については 10 月 3 日以降の検測作業は中止 されており検測值が存在しないため, 改めて主な地震の $\mathrm{P}$ 波の読み取りを行った。しかし光学記録のため $\mathrm{S}$ 相の 検測が困難であり，S-P 時間を用いた震源決定には利用

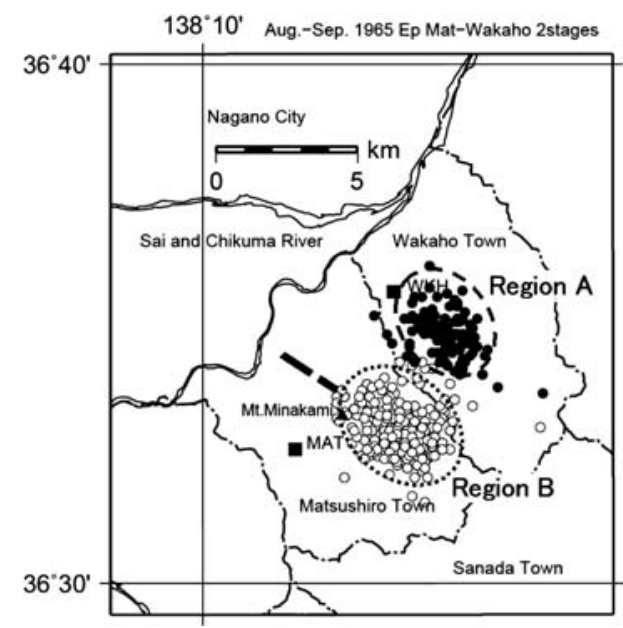

Fig. 11. A summary of the early development of the Matsushiro earthquake swarm in August and September, 1965. While solid circles around border area of Matsushiro-town and Wakahotown represent swarm activity started in early August (Region A), open circles represent activity isolated from the initial activity and newly born in late August and early September (Region B). Activity in the region $B$ leads to the development of further swarm activity after October, 1965.

できない。そのため $\mathrm{P}, \mathrm{S}$ 相を用いた震源決定には 6 点 を，S-P 時間を用いた震源決定は 5 点の観測值を使用し た。速度構造については, 気象庁の標準速度構造 [JMA2001，上野・他(2002)］を用いた。 JMA2001は松 代地域に当てはめるには, 速度が速すぎると考えられる が, 震源域を囲む多点の震源決定には大きな影響はない と判断されるためである。

観測網の大きさと時刻精度の兼ね合いで S-P 時間を用 いた震源決定と, P, S 相を用いた震源決定の両方を行っ て結果を比較した。10月から 12 月に発生した地震につ いて Fig. 12 に両方を比較した結果を示す。震源の広が りは両者に大きな違いはないが, S-Pを用いて決めた震 源の方がよくまとまっている. またFig. 13 に示す震源 の深さ分布を見ても S-P 時間を用いて決めた震源の方が 深さのまとまりがよく, $0 \mathrm{~km}$ 震源も少ないことから, S-P 時間による震源の方が精度良く決まっていると判断 される. 震源の深さは, いずれの方法で決めても4-5 $\mathrm{km}$ 前後に決まり, 震研観測班 (1966) の結果とも一致す る。これらの地震の内 S-P 時間による震源と, P, S を用 いて決めた震源の震央の違いが $3 \mathrm{~km}$ 以内の信頼度の高 い震源を Fig. 14 示す. Fig. 14.には, 1967 年になって 


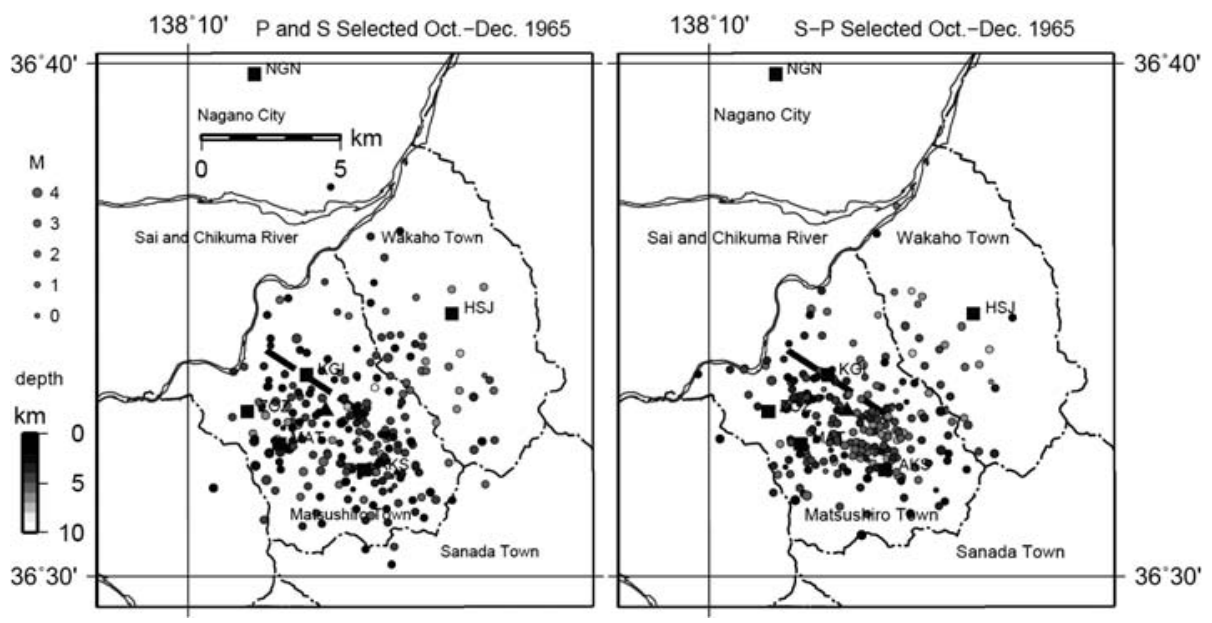

Fig. 12. Swarm activity during the period from October through December, 1965. Hypocenters located using $\mathrm{P}$ and $\mathrm{S}$ arrival times from six stations (MAT, NGN, KGI, HSJ, ZOZ and AKS) are on the left and located using S-P data from five stations (NGN, KGI, HSJ, ZOZ and AKS) are on the right showing higher reliability of S-P hypocenter location with smaller scattering of epicenters.

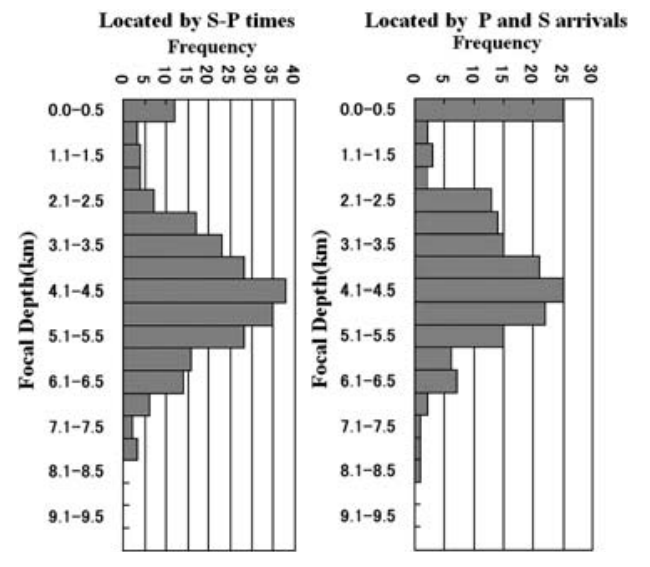

Fig. 13. A comparison of the frequency of focal depths of the swarm located using S-P times in the left and using $\mathrm{P}$ and $\mathrm{S}$ arrival times in the right. The concentration of determined focal depth around $4-5 \mathrm{~km}$ in the left is more prominent than those in the right suggesting better quality of hypocenter location using S-P times.

群発地震の活動が最盛期を迎えた時期に地下水の涌水が 起きた地域 [中村 (1971)］も併せて示す。震研観測班 (1966)による1965 年 10 月の震源を比較のために Fig. 15 に示す. Fig. 14 と Fig. 15 に示す結果は全体としては よく一致している。期間の長さの違い, 震研観測班 (1966) では有感地震だけを表示しているなどの違いはあ るが分布のパターンは一致しており,この時期の活動は

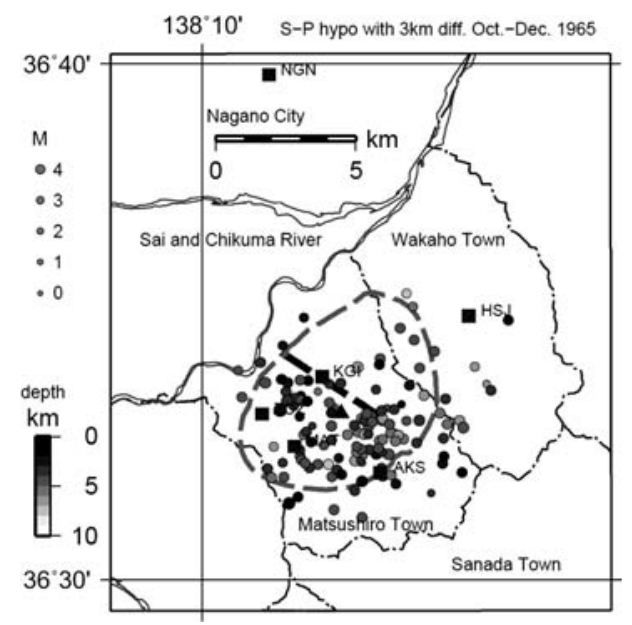

Fig. 14. Swarm activity during the period from October through December, 1965. Reliable hypocenters of which epicentral differences between $\mathrm{S}-\mathrm{P}$ located epicenter and $\mathrm{P}$ and $\mathrm{S}$ located epicenter were less than $3 \mathrm{~km}$ are shown. The area en-circled by the broken line is after Nakamura (1971) showing the area experienced gushing out of large amount of ground water in the climatic stage of the swarm activity after April, 1966.

松代地震断層の南西側が中心であったことを示してお り, Fig. 9 に示した 8 月中の初期の活動との違いは明暸 である. Fig. 11 に示したB 領域と, Fig. 14, Fig. 15 に 示す地震活動域とは, 水平方向に $3 \mathrm{~km}$ 程度のずれがあ 


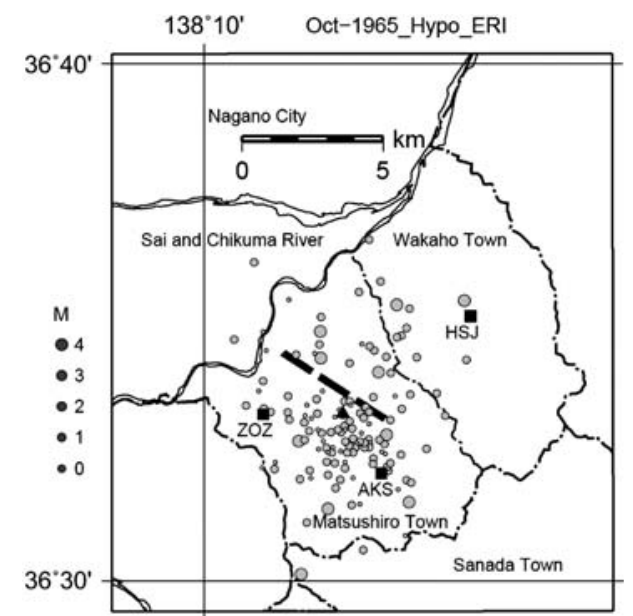

Fig. 15. Hypocenters of the swarm in October, 1965 which appear in the Figure 4 of the party for seismographic observation of Matsushiro earthquakes and Seismometrical section (1966) shows similarity in epicentral distribution with those indicated in the Fig. 14.

る. 若穂 (WKH) の表層を薄くする或いは震源を深く仮 定する, 或いは松代の速度構造を少し遅いものに変えれ ば, 震央は松代 (MAT) の方向に移動するので, Fig. 11 の B 領域を Fig. 14, Fig. 15 に示す地震活動域に近づけ ることは可能であるが，9月下旬から 10 月上旬にかけ て活動域の拡大や移動も十分考えられる. しかしこの差 は, 仮定した松代, 若穂の地下構造の誤差に由来する可 能性が高いと考えられる。 そう考えればFigs. 14, 15 に 示す, 松代地震断層の南部, 皆神山の南東部の震源が密 集した部分が本来の B 領域である可能性が高い.

\section{§6. 議 論}

松代群発地震の活動は, Hagiwara and Iwata (1968) による 5 期の区分が広く受け入れられている (Fig. 1). それによれば活動の第 1 期は, 1965 年 8 月から 1966 年 の 3 月までとされている. 地震の発生様式の違いなどか ら Matsu'ura and Karakama (2005) はさらに6つの期間 と 1 つの遷移期間に分けているが, 第 1 期については, Hagiwara and Iwata (1968)の区分と同じである.いず れも初期には群発地震活動は徐々に活発化したものの, 地震の発生様式や活動域には大きな変化はなかったとの 評価に基づくものであろう。しかしながら今回の調査に より，第 1 期のごく初期の 1965 年 8 月から 9 月にかけ て群発地震活動の活動域の変化と移動が, 初めて明らか となった．地震の規模も小さく活動は小規模ではある
が, 群発地震の活動域の拡大はこの時期にすでに始まっ ていたといえる.

群発地震活動は 1966 年 3 月以降の活動の第 2 期に入 ると, 南西-北東方向に活動域が本格的に拡大を始めた が, その活動の中心は初期の活動の内, 1965 年 9 月か らの B 領域, 南西側の活動域に対応している。1965 年 8 月初期の A 領域, 北西側の活動域では, Fig. 6 (d) に 示すように地震活動が 1965 年 9 月後半に入ると衰えて いるが, その後の活動の消長は, 南西側の活動の活発化 と活動域の拡大により吞み込まれて見えず, Fig. 13 に 示す今回の調査でも, B 領域とは独立した活動域として 存続したかは判別できない. しかし1966 年 4 月後半か ら 7 月にかけての群発地震の震源を新たな検測值を追加 して再検討した野坂・他 (2011) の結果によれば, 独立し た活動として継続しているようにも見える。地震月報に 掲載されている群発地震の震源を再調査した浜田 (1987) も, 期間を通して見ると松代地震断層付近では群発地震 活動が周囲に比べて低く, 大きな地震の発生が集中して いたわけでもないことから, 松代地震断層自身は地震に よる変位ではなく, クリープ的にずれた可能性を指摘し ている、いずれにせよ, 最初に群発地震が始まった $\mathrm{A}$ 領域と, 後から活発化した B 領域の間には, 地下構造, 応力状態などに不連続があることを示唆している.

また第 4 期の 1967 年 1 月以降になると, 群発地震の 活動は南西-北東方向に活動域が拡大し, B 領域を中心 とした中心部では活動が衰え空白を生じ, 全体の活動は 北西側と南西側に分離し徐々に活動が低下していった. その後の松代群発地震の活動の低下は, 涌井 (1976) など にも報告されているが, 活動レベルは低下したが, 活動 域には変化はほとんど忍められない.

1980 年代後半の地震活動については, 松代の群列地 震観測システムと臨時観測デー夕を用いた柿下・他 (1990)による詳しい調查がある (Fig. 16). それによれば, 松代地震断層の南側を中心とした B 領域の活動は消滅 し, 松代地震断層の北西延長部分と, 断層の北東側の $\mathrm{A}$ 領域に相当する部分に微小地震活動が認められる. Fig. 17 は 1998 年 10 月以降 2011 年までの 10 年余の期 間の気象庁一元化震源について, 改めて Double Difference 法 [DD 法, Waldhauser and Ellsworth (2000)] を 適用して震源を決めな扔した結果を示す. Fig. 17 から は, Fig. 16 に認められる松代地震断層の北部の活動や, 北東側の震源の線状配列は認められない. Fig. 17 は広 域観測網のデータを使い DD 法を適用したものの, 狭域 の群列観測網や臨時観測により求められた Fig. 16 の震 源ほどの分解能や精度がないためであろう。しかし B 領域の活動が空白であることは共通しており, 周辺の活 


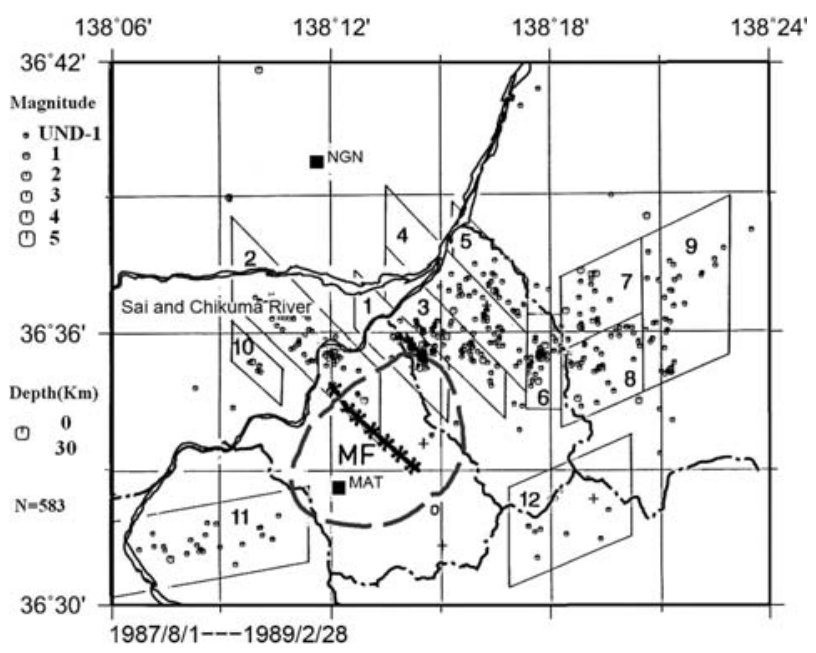

Fig. 16. Hypocenters around Matsushiro area during the period from Aug. 1987 through Feb. 1989 located using data of the Matsushiro seismic array and the temporal observation reported by Kakishita et al. (1990). Geographical information is incorporated in the Figure 2 of Kakishita et al. 1990.

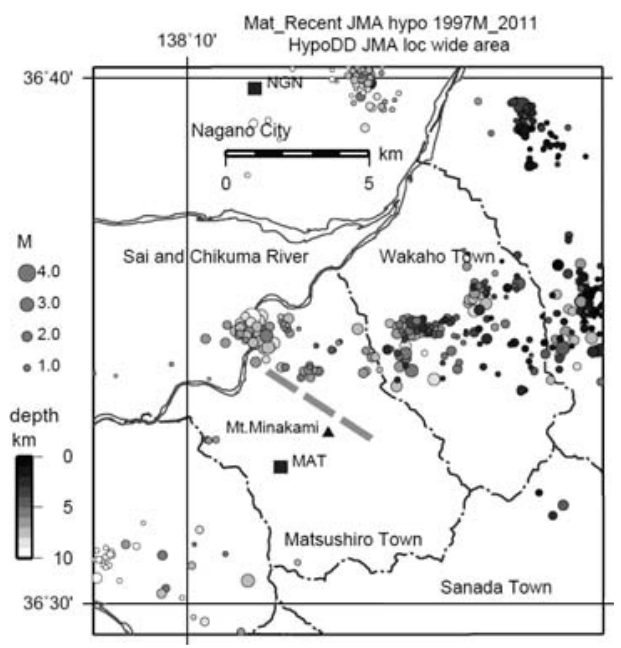

Fig. 17. Recent seismic activity around Matsushiro area during the period from Oct., 1997 through Sep., 2011. Hypocenters are relocated by using the double difference algorithm developed by Waldhauser and Ellsworth (2000). While micro earthquakes are occurring in the region $\mathrm{A}$ of the Fig. 11, seismicity around region B disappeared completely.

動も Figs. 16, 17 は同じようなパターンを示しており， 群発地震終息後の微小地震活動の様子は, 活動度の低下 を別にすれば 40 年間ほとんど変化はなかったと考えら
れる. 群発地震のごく初期の活動域（領域 A）と今日 微小地震活動が残っている地域がほぼ一致することは, 興味深い現象である. 松代群発地震の活動は, 地殼下部 からの大量の深層地下水の供給が関わっていることが推 定されて㧍り [大竹(1976)], 深層水についての起源に ついては色々な説が提出されているものの, 深層地下水 の上昇が群発地震発生の主たる要因であるとの見解が広 く支持されている [例えば, Wakita et al. (1978), Mogi (1988), 奥澤・塚原 (2001), Matsu'ura and Karakama (2005)，塚原・吉田(2005) など]。しかし最初に活動が始 まった A 領域は, Fig. 14 に示す湧水のあった領域の端 もしくは外側に位置する。また, 地下水の湧出が認めら れるようになったのは, 1967 年 1 月以後であることか ら, $\mathrm{A}$ 領域の初期の活動は, 地下水の湧出, 上昇との 直接の関倸は薄いと考えるべきであろう。地殼変動につ いても $\mathrm{A}$ 領域は大きな地殼変動の起きた地域の周辺域 にあたる [Kasahara (1970)]. 一般的な地喨歪の蓄積と応 力の増加により地震活動が始まったとみるのが妥当であ ろう。それに対し後から活動が始まった B 領域は, 地 下水の湧出が最も激しかった地域と一致し, その後の群 発地震活動の中心となった地域である。今日 B 領域で は微小地震活動すら認められない, B 領域では, 群発地 震により, 大地震のアスペリテイ領域のように応力が完 全に解放されたか, 深層地下水の上昇が止まり, 地款上 部の間隙水圧が低下して, 地殼上部の強度が回復したか のいずれかの現象が起きたことを示唆している。いっぽ 
う $\mathrm{A}$ 領域で微小地震活動が今日まで認められることは, この領域では地殼応力が低下したにしても完全には解放 されていないことを示唆している.

\section{§7. ま と め}

1965 年 8 月から始まった松代群発地震の初期発展過 程を明らかにするために, 当時の地震計記録の再読み取 りと,これまで利用されていなかった赤柴, 若穂におけ る気象庁の臨時観測の記録の読み取りを新たに行い, S-P 時間の各観測点の組み合わせやその他の情報を用い て初期の群発地震の活動域を推定した。 その結果 1965 年 8 月に始まった群発地震の活動域は, 従来想定されて いた松代町の皆神山付近ではなく, 北東側の若穂町を中 心として地域（A 領域）にあったことが明らかとなっ た, また 9 月に入ると最初の活動域から南西に離れた松 代地震断層の南東側（B 領域）で新たな活動が始まり, その後の群発地震活動の中心となっていった. 群発地震 活動の活動域が北東から南西へと早い段階で分かれ拡大 したことが, その後の群発地震の活動域が北東南西方向 に分離拡大につながっていったと考えられる.

群発地震終息後は, 南西側 $\mathrm{B}$ 領域の地震活動はほぼ 完全に消滅し空白となったが, 北東側 A 領域では今日 な敃微小地震活動が認められる, B 領域は, 群発地震活 動の最盛期に大量の地下水の湧出が起きた地域と一致し ており, 地下水の湧出が衰えると共に地震活動が低下 し, 群発地震活動が終息後は, 微小地震活動すら認めら れなくなった。このことは地殼内で発生する大地震の震 源域で減衰しながらも長期にわたって余震活動が続く場 合とは, 様相が異なる. 深層地下水の上部地殼への供給 と停止が, 群発地震活動の消長に大きな役割を果たした とする, これまでの各種の研究結果を支持するものであ る.

\section{謝辞}

本研究には古い地震計記象紙の調查が重要なため, 気 象庁精密地震観測室の職員には記象紙の調査に多大の便 宜をはかって頂きました。 また浅間山の火山性震動観測 の記録の読み取りには, 気象庁火山課の飯島聖技官の協 力を得ました．地震研究所の臨時観測結果の利用につい ては, 保存されている検測簿の借用, 利用に関しては元 職員の野口和子氏に便宜を図っていただきました，多く の図の作成にはGeneric Mapping Tools [Wessel and Smith (1998)] を活用しました. 最近の地震活動の調査に は, 国土地理院, 北海道大学, 弘前大学, 東北大学, 東 京大学, 名古屋大学, 京都大学, 高知大学, 九州大学, 鹿児島大学, 独立行政法人防災科学技術研究所, 同海洋
研究開発機構, 同産業技術総合研究所, 東京都, 静岡県, 神奈川県温泉地学研究所, 横浜市, 拉よび気象庁の観測 データを気象庁・文部科学省が協力して処理した, 気象 庁一元化震源カタログを利用しました。 以上関係の 方々, 関倸機関に感謝します。

\section{文献}

Asano, S., S. Kubota, H. Okada, M. Nogoshi, H. Suzuki, K. Ichikawa, and H. Watanabe, 1969, Explosion seismic studies of the underground structure in the Matsushiro earthquake swarm area, J. Phys. Earth, 17, 77-90.

Hagiwara, T. and T. Iwata, 1968, Summary of the seismographic observation of Matsushiro swarm earthquakes, Bull. Earthq. Res. Inst., 46, 485-515.

浜田信生, 1987, 日本列島の内陸部に発生した被害地震 に伴う地震活動の再調査とその地震学的意義, 気像研 究所研究報告, 38, 77-156.

浜田信生・柏原静雄, 1981, 松代に掞ける地殼変動観測 に関する諸問題について, 験震時報, 45, 49-83.

本間直樹 - 石川有三・小林正志 - 小山卓三, 2006 , 松代 群発地震当時の臨時観測点の再調査と震源再計算, 気 象庁精密地震観測室技術報告, 23，101-106.

Ichikawa, M., 1969, Matsushiro earthquake swarm, Geophys. Mag., 34, 307-331.

柿下 毅・森田裕一・西脇 誠・流 精樹 - 長田芳一, 1990, 最近の松代地震の震源過程一松代アレイと臨時 観測デー夕の解析一, 験震時報, 53, 31-44.

Kasahara, K., 1970, The source region of the Matsushiro swarm earthquake, Bull. Earthq. Res. Inst., 48, 581-602.

気象庁, 1968, 松代群発地震調查報告, 気象庁技術報告, 62, 556pp.

北村良江・小林正志・春原美幸・伊藤 優, 2006, 地震 観測原簿の電子媒体化 (1949-1973), 気象庁精密地震 観測室技術報告，23，83-91.

松代地震センター, 1982 , 松代地震センター 15 年のあ ゆ2, 防災科学技術研究所, 34pp.

Matsu'ura, R. S. and I. Karakama, 2005, A point-process analysis of the Matsushiro earthquake swarm sequence: The effect of water on earthquake occurrence, Pure Appl. Geophys. 162, 1319-1345.

Mogi, K., 1988, The mechanism of the occurrence of the Matsushiro earthquake swarm in central Japan and its relation to the 1964 Niigata Earthquake, Techtonophysics, 159, 109-119.

南雲昭三郎・高橋 博 - 長谷川 淳, 1967, 気象庁地震 観測所坑内に打ける弾性波速度測定, 防災科学技術総 合研究速報, 5, 49-55.

中村一明, 1971, 松代地震から学んだこと, 科学朝日 (10 月号), 127-133.

Nakamura, K. and Y.Tsuneishi, 1966, Ground cracks at Matsushiro probably of underlying strike-slip fault origin, I-preliminary report, Bull. Earthq. Res.. Inst., 44, 1371-1384. 
野坂大輔 - 吉川一光 - 牧野 優 - 熊井富美子 - 浜田信 生, 2011, 長野地方気象台における松代群発地震観測 記録の資料化, 気象庁精密地震観測室技術報告, 28 , 71-83.

奥澤 保・塚原弘昭, 2001, 松代群発地震地域に湧出す る深層地下水, 地震 $2, \mathbf{5 3}, 241-253$.

大竹政和, 1976, 松代地震から 10 年, 科学, 46, 306313.

長田芳一 - 柏原静雄・永井 章・高山寛美・涌井仙一 郎・森下 功・田中義彦, 1984, 群列地震観測システ 厶について (I), 気象庁地震観測所技術報告， 5, 1331.

The party for seismographic observation of Matsushiro earthquakes and Seismometrical section, 1966, Matsushiro earthquake observed with temporary seismographic network (Part 1), Bull. Earthq. Res. Inst., 44, 309-333.

塚原弘昭・吉田則夫, 2005, 松代群発地震を起こした地 下水の素性, 月刊地球, 27, 453-460.
露木貴裕・本間直樹・松島 功・小山卓三, 2009, ボア ホール地震計の設置について, 気象庁精密地震観測室 技術報告， 26, 1-16.

上野 寛 - 畠山信一 - 明田川 保 - 舟崎 淳 - 浜田信 生, 2002, 気象庁の震源決定法の改善一浅部速度構造 と重み関数の改良一, 験震時報, 65, 123-134.

涌井仙一郎, 1976, その後の松代群発地震の活動につい て, 験震時報, 41, 21-30.

Wakita, H., N. Fujii, S. Matsuo, K. Notsu, and N. Takaoka, 1978, "Helium spots": Caused by a diapiric magma from the upper mantle, Science, 200, 430-432.

Waldhauser, F. and W. L. Ellsworth, 2000, A double-difference earthquake location algorithm: Method and application to the Northern Hayward fault, California, Bull. Seismol. Soc. Am., 90, 1353-1368.

Wessel, P. and W. H. F. Smith, 1998, New, improved version of Generic Mapping Tools released, EOS Trans. Am. Geophys. Union, 79, No. 47, 579 pp. 